\title{
Opinion and Constraints Analysis in Horticulture Development under Tribal Area Development Programme on Tribals of Udaipur District
}

\author{
Sonali Sharma ${ }^{1 *}$, Snehlata Maheshwari ${ }^{2}$, Rajshree Upadhyay ${ }^{2}$, \\ Bhupendra Upadhyay ${ }^{3}$ and H.R. Sain ${ }^{4}$ \\ ${ }^{1}$ Home Science, KVK-Barmer (Raj.), India \\ ${ }^{2}$ Department of Home Science Extension and Communication Management, College of Home \\ Science, MPUAT, Udaipur, India \\ ${ }^{3}$ Department of Statistics, Rajasthan College of Agriculture, MPUAT, Udaipur, India \\ ${ }^{4}$ Agriculture Extension, KVK-Barmer (Raj.), India \\ *Corresponding author
}

\section{A B S T R A C T}

\begin{tabular}{|l|}
\hline K e y w o r d s \\
$\begin{array}{l}\text { Horticulture } \\
\text { development, } \\
\text { Tribal area } \\
\text { development }\end{array}$ \\
\hline Article Info \\
\hline $\begin{array}{l}\text { Accepted: } \\
\text { 07 November } 2018 \\
\text { Available Online: } \\
\text { 10 December } 2018\end{array}$ \\
\hline
\end{tabular}

\section{Introduction}

The tribals form an integral part of India's social fabric and have second largest concentration of tribal population in the world after that of the African continent. Tribals are most primitive people living in isolation and constitute 8.61 per cent of the total population of the country, numbering 104,281,034 millions, out of which $93,819,162$ residing in rural area and 10,461,872 living in urban area. The country's 15 per cent of the total
Tribal Development in India is a big challenge as the gap between the ideal and reality is not only woeful but widening with the passage of time. The study was conducted in Udaipur district of Rajasthan as for the development of tribals a separate department i.e. Tribal Area Development Department is in function. These Horticulture Developments were being implemented in seven tribal blocks of Udaipur district at the time of planning the study namely Jhadol, Sarada, Lasadiya, Kotra, Kherwara, Gogunda and Salumber. Over all it can be concluded Horticulture Development, all the beneficiaries had ble opinion also reflected in MWS i.e. 2.60. The personal, technical, economic and general constraints were faced by the beneficiaries to great extent in all the services. In Horticulture development, 50.00 per cent beneficiaries were falling in each great and some extent constraints categories reflecting the constraints to great extent in MPS 66.76. 
as each tribe has different socio-economic situation, environment, historical experience and the extent of political articulation. On account of these factors, ethnically as well as culturally the tribes remain at different stages of socio-psychological orientation and political economic development.

Rajasthan is the largest state in the country having geographical area of 3,42,339 sq. km or 10.41 per cent of the total geographical area of the country. The population of Rajasthan according to Census 2011 stands at about 68 million, making it the 8th most populated state in India, the population of Scheduled Tribe is $9,238,534$, further in rural areas 8,693,123 tribal and 545,411 tribal in urban areas of the state, but the concentration of the ST population is greater in some parts of the state.

With the view to bring the tribal areas or people of the country in the mainstream of economic development and accelerating the pace of socio-economic development, the State Government has made significant efforts to uplift the tribal people and started various activities for their social and economic development. A special programme, known as Tribal Area Developmental Programme (TADP) was taken up, on a pilot basis under a central sector plan scheme of the Ministry of Agriculture in 1964.

\section{Objectives of the study}

To study the opinion of beneficiaries towards Horticulture Development promoted under TADP.

To explore the constraints faced by the beneficiaries of the TADP.

Opinion - Opinion in the present study is conceptualized as the personal view of tribal beneficiaries - positive or negative about agricultural services promoted under Tribal Area Development Programme.
Constraints - It refers to the obstacles in adoption of improved practices of agricultural services by the beneficiaries of TADP.

\section{Materials and Methods}

The study was conducted in Udaipur district of Rajasthan as for the development of tribals a separate department i.e. Tribal Area Development Department is in function. These Horticulture Development were being implemented in seven tribal blocks of Udaipur district at the time of planning the study namely Jhadol, Sarada, Lasadiya, Kotra, Kherwara, Gogunda and Salumber.

\section{Selection and development of research tool}

In view of the study objectives and nature of respondents, interview technique was selected for data collection. This technique was considered most appropriate technique to collect in-depth information from tribals, as it help in face-to-face interaction along with clarification of doubts if any. The interview schedule was developed by the researcher after extensive review of literature, material collected from the concerned departments and organization and in consultation with the subject matter specialists from the discipline of Agronomy, Animal Husbandry, Horticulture and Extension Education from Maharana Pratap University of Agriculture and Technology, Udaipur.

Scoring procedure - The scoring of the schedule was finalized in consultation with the expert. The scoring in part of the interview schedule was as follows:

Opinion - It consists of positive and negative statements in each service therefore assessed on three point continuum as agree, undecided and disagree with the scores of 3,2 and 1 respectively for positive statement and 1, 2 and 3 respectively for negative statements. 
Constraints tool - Constraints were assessed on three point continuum as Great extent, some extent and least extent with scores 3, 2 and 1 respectively.

\section{Measurement of opinion}

The respondent's opinion towards positive and negative statements in Horticulture Development was measured.

\section{Measurement of constraints}

There were varied number of constraints in each Agriculture service grouped under Personal, technical, economic and general constraints.

After collecting data it was necessary to analyze with the help of statistics to derive proper and adequate conclusion. Therefore, obtained data were coded, tabulated and analyzed with the help of statistical tools and techniques

\section{Results and Discussion}

\section{Opinion of beneficiaries towards horticulture development}

Opinion of the beneficiaries was studied towards Horticulture Development promoted under TADP. The statement wise results are presented in Table 1 and 2.

\section{Horticulture development}

The opinion of the beneficiaries towards Horticulture Development presented in Table 1 reveals that 80 to 93.33 per cent of the beneficiaries agree that aonla growing is profitable, cheap technology has brought significant change in economic status, requires less technical skills in cultivation and TADP personnel gave adequate knowledge about its cultivation. However majority of the beneficiaries disagree towards marketing problem (100\%), input intensiveness (86.66\%), labour intensive activity (80\%), perishability $(63.33 \%)$ and crop's susceptibility to diseases, insect, pest and infestation (56.66\%). Based on these findings, it can be said that beneficiaries liked aonla cultivation.

\section{Constraints faced by the beneficiaries of Horticulture development programme}

The constraints faced by the beneficiaries of Horticulture Development Programme presented in Table 2 clearly reveals that the major constraints faced by the beneficiaries of the service were personal, technical and economic with MPS 73.33, 70.37 and 66.3 and rank I, II, III respectively followed by general constraints (55.11 MPS) ranked IV. A critical look of the table reveals that the major personal constraints perceived by the beneficiaries of Horticulture Development were non - cooperation from family members (92.22 MPS), lack of awareness about aonla products and their medicinal importance (87.78 MPS), followed by lack of interest (72.22 MPS) and lack of scientific orientation (67.78 MPS). Lack of knowledge (64.44) and increased workload (55.55 MPS) were also reported by the beneficiaries of the service to some extent.

Regarding technical constraints, Table 2 shows that the beneficiaries of the service faced the major constraints as lack of skill in using modern irrigation system (drip/sprinkle) (84.3 MPS), Long unproductive period (83.33 MPS), protection of crops from insect and pests (77.67 MPS) and inadequate knowledge of manure and fertilizers application (70 MPS). Unavailability of improved varieties (58.67MPS) and timely technical guidance (47.67 MPS) were the constraint experienced to some extent by the beneficiaries of the service. These constraints were due to the 
reason that scientific or technical names of varieties, insecticides and pesticides were tough to learn for beneficiaries and technical guidance is another lacuna. Sometimes due to limited staff also the service is not implemented fully.

The economic constraints in Horticulture Development (Table 2) experienced by the beneficiaries reveal that Price fluctuation (77.67 MPS), Transportation cost (75.53 MPS) and credit facilities (68.67 MPS) were major constraints experienced by the beneficiaries. Cost of insecticides and pesticides (64.33 MPS), cost of plant materials (62 MPS) and commission of middle men (48.89 MPS) were the other economic constraints faced by the beneficiaries to some extent. Beneficiaries expressed that price varies in selling the vegetables according to season, cost is also high for insecticides and pesticides and face the problem of middle man's commission because selling vegetables directly to consumers was not possible for them because they live in interior place.

Under the general constraints beneficiaries of Horticulture Development Programme expressed the constraints of water and electricity facilities (66.67 MPS) to great extent.

Table.1 Distribution of beneficiaries by their opinion towards Horticulture Development

\section{Programme}

\begin{tabular}{|c|c|c|c|c|}
\hline S.No & Statements & $\begin{array}{l}\text { Agree } \\
f(\%)\end{array}$ & $\begin{array}{l}\text { Undecided } \\
\text { f(\%) }\end{array}$ & $\begin{array}{l}\text { Disagree } \\
\mathrm{f}(\%)\end{array}$ \\
\hline 1. & Aonla growing is more profitable & $\begin{array}{c}24 \\
(80)\end{array}$ & $\begin{array}{c}6 \\
(20)\end{array}$ & 0 \\
\hline 2. & Crop is input intensive & $\begin{array}{c}4 \\
(13.33)\end{array}$ & 0 & $\begin{array}{c}26 \\
(86.66)\end{array}$ \\
\hline 3. & A cheap technology for farmers & $\begin{array}{c}28 \\
(93.33)\end{array}$ & $\begin{array}{c}2 \\
(6.66)\end{array}$ & 0 \\
\hline 4. & $\begin{array}{l}\text { The crop is more susceptible to diseases, insect, pests } \\
\text { and infestation }\end{array}$ & $\begin{array}{c}8 \\
(26.66)\end{array}$ & $\begin{array}{c}5 \\
(16.66)\end{array}$ & $\begin{array}{c}17 \\
(56.66)\end{array}$ \\
\hline 5. & $\begin{array}{l}\text { Aonla production has brought a significant change in } \\
\text { economic status }\end{array}$ & $\begin{array}{c}24 \\
(80)\end{array}$ & $\begin{array}{c}3 \\
(10)\end{array}$ & $\begin{array}{c}3 \\
(10)\end{array}$ \\
\hline 6. & Aonla cultivation requires less technical knowhow. & $\begin{array}{c}27 \\
(90)\end{array}$ & 0 & $\begin{array}{c}3 \\
(10)\end{array}$ \\
\hline 7. & Labour intensive activity & $\begin{array}{c}3 \\
(10)\end{array}$ & $\begin{array}{c}3 \\
(10)\end{array}$ & $\begin{array}{c}24 \\
(80)\end{array}$ \\
\hline 8. & Inadequate facilities for post harvest activities & $\begin{array}{c}23 \\
(76.66)\end{array}$ & $\begin{array}{c}5 \\
(16.66)\end{array}$ & $\begin{array}{c}2 \\
(6.66)\end{array}$ \\
\hline 9. & $\begin{array}{l}\text { TADP personnel gave adequate knowledge about Aonla } \\
\text { cultivation }\end{array}$ & $\begin{array}{c}28 \\
(93.33)\end{array}$ & 0 & $\begin{array}{c}2 \\
(6.66)\end{array}$ \\
\hline 10. & Improves health and nutritional status & $\begin{array}{c}20 \\
(66.66)\end{array}$ & $\begin{array}{c}10 \\
(33.33)\end{array}$ & 0 \\
\hline 11. & Problem in marketing of Aonla or products & 0 & 0 & $\begin{array}{c}30 \\
(100)\end{array}$ \\
\hline 12. & Perishable nature of commodity is not a problem & $\begin{array}{c}11 \\
(36.66)\end{array}$ & 0 & $\begin{array}{c}19 \\
(63.33)\end{array}$ \\
\hline
\end{tabular}


Table.2 Constraints faced by the beneficiaries of Horticulture Development Programme

\begin{tabular}{|c|c|c|c|}
\hline S. No & Constraints & MPS & Rank \\
\hline 1 & \multicolumn{2}{|l|}{ Personal } & \\
\hline i. & Non - cooperation from family members & 92.22 & \\
\hline ii. & Unaware about aonla products and their medicinal importance & 87.78 & \\
\hline iii. & Lack of Interest & 72.22 & \\
\hline iv. & Lack of scientific orientation & 67.78 & \\
\hline v. & Lack of knowledge & 64.44 & \\
\hline \multirow{2}{*}{ vi } & Increased workload & 55.55 & \\
\hline & Over all & 73.33 & I \\
\hline 2 & \multicolumn{2}{|l|}{ Technical } & \multirow{8}{*}{ II } \\
\hline i. & Lack of skill in using modern irrigation system (Drip/sprinkle) & 84.3 & \\
\hline ii. & Long unproductive period & 83.33 & \\
\hline iii. & Protection of crops from insect and pests & 77.67 & \\
\hline iv. & Inadequate knowledge of manure and fertilizers application & 70 & \\
\hline v. & Unavailability of improved varieties & 58.67 & \\
\hline \multirow[t]{2}{*}{ vi } & Timely technical guidance not available & 47.67 & \\
\hline & Over all & 70.37 & \\
\hline 3 & \multicolumn{2}{|l|}{ Economic } & \multirow{8}{*}{ III } \\
\hline i. & Price fluctuation & 77.67 & \\
\hline ii. & Transportation cost & 75.33 & \\
\hline iii. & Credit facilities & 68.67 & \\
\hline iv. & Cost of insecticides and pesticides & 64.33 & \\
\hline v. & Cost of plant materials & 62 & \\
\hline \multirow[t]{2}{*}{ vi } & Commission of middle men & 48.89 & \\
\hline & Over all & 66.3 & \\
\hline 4 & \multicolumn{2}{|l|}{ General } & \multirow{6}{*}{ IV } \\
\hline i. & Water and electricity facilities & 66.67 & \\
\hline ii. & Storage facilities & 61 & \\
\hline iii. & Processing units & 60 & \\
\hline iv. & Lack of technical guidance by extension personnel & 50 & \\
\hline v. & Marketing facilities & 37.67 & \\
\hline
\end{tabular}

Storage facilities (61 MPS), processing units (60 MPS), lack of technical guidance by extension personnale (50 MPS) and marketing facilities (37.67 MPS) were other general constraints faced by the beneficiaries to some extent (Meena, 2005).
Over all it can be concluded Horticulture Development, all the beneficiaries had favourable opinion also reflected in MWS i.e. 2.60. The personal, technical, economic and general constraints were faced by the beneficiaries to great extent in all the services. 
In Horticulture development, 50.00 per cent beneficiaries were falling in each great and some extent constraints categories reflecting the constraints to great extent in MPS 66.76.

\section{References}

A Reference Annual India. 2015. Publications Division - Ministry of Information and Broadcasting (Government of India) pp 86.

Gondalia, V.K. and Patel, G.N. 2007. An Economic Evaluation of Investment on Aonla (Emblica officinalis G.) in Gujarat. Agricultural Economics Research Review 20: 385-394

Jatana, R. and Waldia, S. 2009. Tribal Development Programmes. Mahamaya Publishing House, New Delhi. pp: 14, 46, 82, 83, 109-110 and 120-121.

Jitarwal, R. C. and Sharam, N. K. 2007. Impact of Drip Irrigation Technology among Farmers in Jaipur Region of Rajasthan. Indian Research Journal of Extension Education 7:88-89.

Meena, M. 2005. A study on Adoption of improved technology of Aonla (Emblica officinalis gaertn.) plantation in Udaipur District of Rajasthan. PhD thesis submitted to Maharana Pratap University of Agriculture and Technology, Udaipur, Rajasthan.

Meena, S. R., More, T. A., Singh, D. and Singh, I. S. 2009. Arid Vegetable Production Potential and Income Generation. Indian Research Journal of Extension Education. 9:72-75.

Prasad, R., Singh, A.K., Singh, L. and Singh, A. 2013. Economics of Goat Farming under Traditional low Input Production System in Uttar Pradesh. Journal of Community Mobilization and Sustainable Development, 8: 09-13.

\section{How to cite this article:}

Sonali Sharma, Snehlata Maheshwari, Rajshree Upadhyay, Bhupendra Upadhyay and Sain, H.R. 2018. Opinion and Constraints Analysis in Horticulture Development under Tribal Area Development Programme on Tribals of Udaipur District. Int.J.Curr.Microbiol.App.Sci. 7(12): 474-479. doi: https://doi.org/10.20546/ijcmas.2018.712.059 